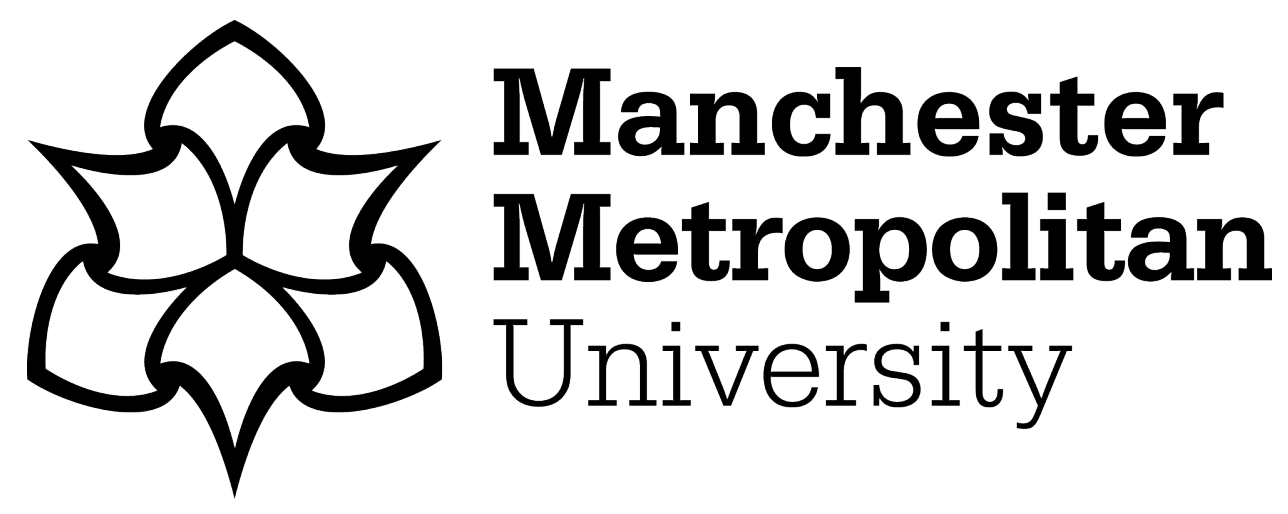

Di Feliciantonio, C and O'Callaghan, C (2020) Struggles over property in the 'post-political' era: notes on the political from Rome and Dublin. Environment and Planning C: Politics and Space, 38 (2). pp. 195-213. ISSN 2399-6544

Downloaded from: https: //e-space.mmu.ac.uk/624204/

Version: Accepted Version

Publisher: SAGE Publications

DOI: https://doi.org/10.1177/2399654419870812

Please cite the published version 


\section{Struggles over property in the 'post-political' era: Notes on the political from Rome and Dublin*}

\section{Cesare Di Feliciantonio ${ }^{1} \&$ Cian O'Callaghan $^{2}$}

${ }^{1}$ National Institute for Regional and Spatial Analysis (NIRSA), National University of Ireland Maynooth, Maynooth, Co. Kildare, Ireland difeliciantoniocesare@gmail.com

${ }^{2}$ Department of Geography, School of Natural Sciences, Trinity College Dublin, Dublin, Ireland

ocallac8@tcd.ie

\section{Abstract}

Geographical analyses on protests against austerity politics using the framework of postpolitics have proliferated in recent years, mostly building on the work of Jacques Rancière and his conceptualization of the political and the police order. The paper continues this tradition but seeks to move beyond those analyses reducing the political gesture to a 'rare' and 'heroic' act. It does so by bridging the work of Rancière with the work of Jean-Luc Nancy, developing two main arguments. The first one concerns the local and situated dimension of the political moment; the second concerns the dialectical relation between the police order and its disruption, while at the same time viewing insurgent acts as part of part of a chain of perpetual acts that destabilise the police order, which moreover are the inevitable outcome of its excess. These theoretical arguments are developed in relation to the analysis of the trajectory of disruptive politics around vacant property in Dublin and Rome. In both cities several contentious political initiatives around property emerged as a response to the crisis and austerity politics, but they were unable to translate into bigger movements. To account for this, the paper identifies two main factors: the limited violence of the crisis in terms of evictions and foreclosures; and the instrumental use of 'legality' and 'rules' by the police order. Nevertheless, we argue, activist engagements with vacant property can be considered as examples of "world forming" (Nancy, 2007) that create the possibilities for further disruptive politics.

* Final draft version of the paper published on Environment and Planning C: Politics and Space, 2019, doi: 10.1177/2399654419870812 
Key-words

post-politics; vacant property; Rome; Dublin; subjectification; world forming

\section{Introduction}

In the context of post-crisis urban and political transformations, how do we interpret the tensions between the deepening of the neoliberal hegemony and the concomitant spread of place-based oppositional movements? Various critical geographers addressing this question have used Jacques Rancière's $(1995,1999,2000)$ framework of the police order and the political to highlight how institutional responses to the crisis have reinforced the neoliberal consensus (i.e. the police order), while autonomous and grassroots groups (heterogeneous and place-based) have challenged neoliberal hegemony by re-opening new political spaces (Dikeç and Swyngedouw, 2017; Garcia-Lamarca, 2017a, 2017b; Karaliotas, 2017; Swyngedouw, 2014). However, most contributions have focused either on the embryonic potentialities of these initiatives or their 'structural' limits. The result is that these conceptualisations are limited by two factors: the over-emphasis on the insurgent moment in the creation of new political subjectivities; and the assumed "all or nothing" character of the "properly political" act (see Temenos, 2017: 587).

In this paper, we argue that by placing Rancière's contributions in dialogue with the political philosophy of Jean-Luc Nancy we can offer a richer account of the conflict between the police and the political as a process of social change. Through this reading we aim to move away from reiterating a very limited vision of the political, and instead emphasise how moments of disruption - even if eventually quelled - are always also characterised by what Nancy (1997) terms the "tying and untying" of relations that continuously form political community and ultimately, iteratively, transform the police order.

We unpack our theoretical argument through an analysis of the trajectory of disruptive politics centred around activist occupations and squatting of vacant property in Rome and Dublin. Although these cities are characterised by important differences, the set of activist responses to vacant property are comparable. Both cities were severely impacted by harsh austerity measures in response to national fiscal crises, have been characterised by exclusionary rental dynamics and associated housing insecurity (Di Feliciantonio, 2016a; 
O'Callaghan, Di Feliciantonio and Byrne, 2018), and contentious political experimentation has become a vivid feature of urban life (Bresnihan and Byrne, 2015; Di Feliciantonio, 2017b). In both contexts, while activist engagements with vacant properties have been prominent and, periodically, highly visible, they have failed to lead to bigger mobilizations. Through a conceptual reading of Rancière through Nancy, however, we argue that we can reframe these political mobilisations in a more affirmative way, while simultaneously acknowledging their limits. Our analysis illustrates both the ways in which the police order deploys discursive and material tactics to disavow the disruption, and how this disavowal is never complete and thus leaves space open for further destabilising political acts. In particular, we emphasise two empirical arguments highlighting the tensions between the political and the police order. The first is a structural factor: in immediate period following the crisis the violence of evictions and foreclosures has been contained, especially in Dublin (although slower forms of structural violence have emerged around homelessness). The second concerns the repressive power of the police order, especially in Rome where alternative initiatives have been foreclosed on and evicted in the name of 'legality' and '(market) rules'. Nevertheless, we argue, activist engagements with vacant property in both cities can be considered as examples of "world forming" (Nancy, 2007) that create the possibilities for further disruptive politics.

Methodologically, the paper brings together two different research projects. The Rome case study is drawn from research conducted by the lead author, which focused on the reemergence of squatting as a political response to the crisis. This project involved a combination of methods: participant observation in activist (squatting) initiatives; 76 indepth interviews (individual or in group) with participants in different initiatives between 2011 and 2014 and 8 follow-up interviews in 2016; a survey (65 respondents) administered to the members of one specific project (Communia) the researcher was involved in since its conception; analysis of policy documents and media discourse. The Dublin case study is drawn from a project worked on jointly by both authors. This project combined a similar set of methods, excluding a questionnaire survey: participant observation in housing activist groups, 29 in-depth stakeholders interviews (including activists, policy-makers, and cultural actors in Dublin as well as Berlin and Barcelona) between 2016 and 2017, supplemented by policy analysis. A smaller sub-section of interviews with activists in both cities are primarily 
drawn on in this paper. The two research projects had overlapping ${ }^{1}$ research objectives. While we acknowledge some difficulties in comparison - both in terms of research design and geographical specificity - we nevertheless believe that the comparison is useful in demonstrating the contextual ways in which even analogous political claims are articulated. Building on Robinson's call (2011) for "comparative gestures" within urban studies against a presumed incommensurability of urban experiences, our comparative effort relies on a relational approach centred around place, subjects and political practices.

The paper is structured as follows. In the next section, we discuss conceptualisations of post-politics and put Ranciere into dialogue with Nancy, while reviewing some of the main contributions in geography, planning and urban studies. In the next section, we briefly analyse the years of the post-political consensus in Ireland and Italy, highlighting the centrality of the property market in neoliberalisation. Section four analyses the political character of initiatives that emerged since the crisis in both cities. Following this, we discuss the two main factors leading to the reaffirmation of the police order in both contexts, i.e. the limited, or delayed, violence of the crisis and the instrumental use of 'rules' to disavow alternative practices. The final section summarizes the argument and contributions of the paper, while arguing, in line with Nancy, that the practices analysed create the possibilities for further disruptive politics.

\section{Rancière, Nancy, and the (post)political}

\section{Staging the political}

Since the early 1990s the triumph of capitalist globalization has been depicted as intertwined with a series of political processes defining a "post-political" or "postdemocratic" condition (Crouch, 2004; Dean, 2009; Žižek, 1999). Democratic institutions have been eroded by the growing power of corporate actors, along with the broad acceptance of neoliberal capitalism and liberal democracy as the dominant model of state governance. Within this context, theorists of post-politics argue, the political arena has been reduced to the technocratic management of specific 'problems' while foundational political

\footnotetext{
${ }^{1}$ The Rome project focused on the practices of squatting while the primary lens of the Dublin project was to consider the role that contestations around vacancy played in the post-crisis city.
} 
questions are effectively foreclosed. Post-political theorists generally agree that the dominant constellation has, at least until recently, diminished the capacity for genuinely transformative politics by instituting "an overall model of elite consensus and agreement" (Swyngedouw, 2009: 610). However, their prognosis on the ways to move beyond such an impasse diverge. For Mouffe (2013), for instance, the institutions of liberal democracy need to be reformulated to better enable "agonistic" politics. For Žižek (1999), conversely, the current conjecture of neoliberal capitalism, liberal democracy, and post-modern identity politics, no longer represses, but forecloses the political. He uses "post-political" as a description of the current era. As such, debates have concerned the extent to which the "properly political" act is still possible within the stifling confines of the neoliberal consensus (Swyngedouw, 2011).

The work of Rancière occupies an important, if ambivalent, position in this regard. Rancière uses the term "post-democracy" rather than "post-politics". Nevertheless, his conceptualization of the police and the political has been fundamental in theorizing the post-political condition (largely based on Žižek's, 1999 reading). For Rancière (1999), the police refers to the broad apparatus of society, including state governance, but also its discursive and aesthetic framing: "The police is thus first an order of bodies that defines the allocation of ways of doing, ways of being, and ways of saying... it is an order of the visible and the sayable that sees that a particular activity is visible and another is not, that this speech is understood as discourse and another as noise" (Rancière, 1999: 29). In contrast, "the political' is an extremely determined activity antagonistic to policing" (Ibid). For Rancière, the political occurs when "the part of no part" (those with no voice) claim a political voice, therefore creating political subjectivities where none existed before, and thus forcing the police order to accommodate a new set of interests.

Rather than in critiquing the neoliberal impasse, however, Rancière's concern is democracy more broadly. For him, democracy is always oligarchic. The police order aspires to be a fully 'inclusive' society, which is never the case: "there will always be a constituted outside, lack or surplus; that what is not accounted for in the symbolic order of the police" (Swyngedouw, 2011: 375). This lack represents the space of possibility for the political to return, within a moment of "disruption" to the oligarchic power by "the part of no part" in the name of "equality". Politics, therefore, only occurs in fleeting moments of 
'disagreement', a point of articulation outside the police order, but which aims at transforming it by naming the "wrong" that exposes the lie of democracy (Rancière, 1995, 1999). For Rancière, such a conflict is at the core of democracy, even though the democratic moment represented by political subjectivation cannot produce a new hegemonic system.

The Rancierian perspective on political subjectivation, the police order, and the political has found fertile ground in geography, urban studies and planning (Dikeç, 2005; Haughton, Allmendinger and Oosterlynck, 2013; O'Callaghan, Boyle and Kitchin, 2014; Swyngedouw, 2009, 2011, 2014; Temenos, 2017). Urban protests represent one of the main topics analysed through this lens (Garcia-Lamarca, 2017a, 2017b; Karaliotas, 2017). For instance, Kaika and Karaliotas (2016) have emphasized the spatial character of the political through an analysis of the occupation of Syntagma square in Athens, which embodies a possible encounter between the police and the political, i.e. politics (although with profound limitations and contradictions).

Garcia-Lamarca (2017a) has used the Rancierian perspective to analyse the practices of the Plataforma de los Afectados por la Hipoteca (PAH) in Spain, meant as manifestations of insurgent citizenship realized by "the part of no part" as "key to the rupture of the indebted subject and create dynamics where positions and identities are reconstituted; in other words, they are processes of political subjectivation" (2017a: 39). Her analysis is not limited to the (short) moment when insurgent practices stage the political but acknowledges how "the PAH uses insurgent practices progressively, employing them as part of an articulated struggle once all institutional ('legal') paths have been exhausted" (p. 50). In this regard, her work makes an important intervention in the debates regarding disruptive politics, arguing that:

“...while insurgent practices are disobedient acts that create subjects, other solidarity-based spaces where sustained learning and critique can take place over time are equally important for people to develop a capacity for expression that did not exist previous to their engagement in collective assemblies or direct action" ( $p$. 49)

This raises an often overlooked component of Rancière's conceptualisation of political subjectification. For Rancière, the cultivation of practices, spaces, and speech (where there was previously only "noise") is necessary to sustain the daily construction of a new political 
subjectivity. Rancière's (1999) uses "the proletariat", for example, to illustrate how new subjectivities produce distinct political demands that force the police order to accommodate new interests. It was through the fertile ground opened up through worker-run newspapers, journals and poetry, and the spaces outside of the factory that gave these utopian visions material form, that the proletariat was actually constituted as a political subjectivity (Rancière, 2012). Likewise, Garcia-Lamarca (2017b: 430) demonstrates how in the case of the PAH political subjectivation is "a fluid, on-going and co-constitutive process that is initiated in collective advising assemblies, circulating through spaces where actions unfold back and forth".

As the foil for debates on post-politics, Rancière's theories of the police and the political have been critiqued in circular ways. On the one hand are those who view the dominant application of post-political theory as signalling the foreclosure of politics, with the political reduced to 'rare' 'heroic' acts (Beveridge and Koch, 2017). On the other hand are those for whom Rancierarian conceptualisations of the political draw attention to the inevitability of rupture through his insistence on a constitutive outside of the fabrication of "society" (Derickson, 2017). Rancière's work is at once critiqued for its circumscribed view of the "properly political" act and for its refusal to imagine a radical break with the police order. Considering Rancière in relation to the political writings of Jean-Luc Nancy can help move beyond this impasse.

\section{The tying and untying of (political) community}

The core of Jean-Luc Nancy's political writing centres around thinking on "community". Starting with "The Inoperative Community", an essay originally published in 1983 before being reworked as part of a longer collection under the same title (1991), Nancy has probed the question of how to think a form of community ("or communism") that escapes the trap of totalitarianism, or indeed all structuring "myths" that a-priori shape the direction of politics.

Nancy advances a conceptualisation of politics as "interruption": Rejecting as "myth" the prospect of finitude or the "completion" of revolution, he advances a notion of "myth interrupted" through a form of politics "that can be named, for want of a better term, 
writing, or literature" (1991: 71). This conceptualisation is not discursive per se, but rather "its essence is composed only in the act that interrupts, with a single stroke - by an incision and/or inscription - the shaping of the scene of myth" (p. 72; see also 2016: 119). Community, in Nancy's formulation, needs to consistently "unwork" itself through "writing" that "interrupts" the completion of politics in favour of "...the political of the beingtogether" (1997: 88).

In later work, Nancy acknowledged that in The Inoperative Community "the meaning of 'politics' was loosely determined sometimes confused with 'community'” (Nancy, 2016: 73). Acknowledging also "that unworking is necessarily derived from the work" (Ibid: 53), he conceptualizes "political writing" as occurring against existing frameworks. In The Creation of the World or Globalization (2007), Nancy operationalises these concerns in distinguishing between globalization, meant as the mode of bringing the world into "view" through the processes bound up in capitalism's enclosure, and world forming, i.e. the proper "taking place" in the world. To "create the world" is therefore part of a politics of "interruption" that seeks to struggle against globalization's "destruction" of the world. For Nancy (1997: 54-55), the dilemma posed by a post-Christian world, and indeed a world after "myth", is the extent to which philosophy, as a basis for knowing the world, has hitherto been reliant on "the Christian sense of world". That is, an objectively experienced world independent of a situated and relational "sense of the world". For Nancy, therefore, each interruption that forms community is a "singular-plural" "recommencement" that aims at "thinking the world anew" (1997: 36; see also 2000). In this sense, "world forming" can no longer rely on structuring theological or political "myths". Rather, the "political question" is

"...how to induce the group comprised of indeterminate ties - ties that have come untied or are not yet tied - to configure itself as a space of sense that would not be reabsorbed into its own truth... [To] trace the form of being-toward in beingtogether without identifying the traits of the towards-what or toward-whom, without identifying or verifying the 'to what end' of the sense of being-incommon..." (Nancy, 1997: 90). 
Notwithstanding differences (see Watkin, 2013), we argue there are convergences between Nancy's conceptualisation of community and Ranciereian politics ${ }^{2}$. Rancière and Nancy's writings on politics are framed in terms of a socio-spatial and discursive order - what Nancy designates "as 'the organisation of society' (Ranciere in a much more brutal manner calls the 'police')" (Nancy, 2016: 11) - that is "disrupted" or "interrupted" by the political. This reinforces the need to distance Rancierian "post-democracy" (disavowal of politics) from the "post-political condition" (foreclosure of politics). To the extent that the police equates to Nancy's (1991) "organisation of society", it is an inherently contingent and unstable constellation of forces. The "return of the political" is inevitable, albeit disavowed. More significantly perhaps, the political act can only ever be a partial destabilisation (reformulation) of the police order if it is to escape the trap of totalitarianism. But neither is the opening produced by the political irrevocably closed by the police. Rather, and to preposition our empirical arguments, firstly, "disruptive politics" comes from a position of being-in-the-world relational to the police order; therefore, the political is always local, situated, and enacted through particular (urban) spaces. Secondly, and consequentially, because the political is local and particular, it is limited and the police order will work to cover over the disruption. However, the police order is potentially fundamentally transformed by the disruption of the political, even if it accommodates and "accounts" for new political subjectivities. In this sense, the political "is less a tie that binds than the tie that reties, less the tie than encloses than the tie that makes up a network" (Nancy, 2016: 114).

\section{Boom, boost and the neoliberal consensus in Italy and Ireland}

Theorists arguing that we have entered an era of post-politics associate this with the rise and triumph of neoliberal rationality (Žižek, 1999). Geographers, however, have shown how

\footnotetext{
2 In Disagreement, Rancière (1999: 37, 143) emphasises the "literary" character of political subjectification referencing Nancy (1997): "The modern political animal is first a literary animal, caught in the circuit of a literariness that undoes the relationship between the order of words and the order of bodies that determine the place of each". He further references the "in-between" nature of politics: "the political community is a community of interruptions, fractures, irregular and local, through which egalitarian logic comes and divides the police community from itself" (Rancière, 1999: 137). Likewise, Nancy (2000: 21-28) discussion of "political philosophy" acknowledges a debt to Rancière's dialogue in Disagreement, and references Rancière's "wandering labour of sense" (Nancy, 1997: 115) to advance his ideas of political community as the incessant "tying and untying of knots".
} 
neoliberalization is an uneven, "path dependent", and partial process (Brenner, Peck and Theodore, 2010). In line with our argument about the local and situated nature of the political moment, it is therefore useful to briefly frame the context of neoliberalisation in Italy and Ireland, in particular its relationship to real estate and construction bubbles (Di Feliciantonio and Aalbers, 2018; Kitchin et al, 2012).

In Italy, between 1997 and 2006, housing construction increased by 40\%, house sales doubled, national real estate values increased by $63 \%$ (but doubled in cities such as Milan and Rome) and the growth of investment in construction doubled GDP growth (Tocci, 2009). This represented the continuation of a long-standing process based on creating political consensus and fuelling economic growth by favouring homeownership (Di Feliciantonio and Aalbers, 2018), while marginalising social housing and reinforcing the ideology of private property.

All these measures centred around the valorisation of property and, more generally, the primary role that rent played in alleviating the uneven restructuring of the Italian economy following the 1970s. Many industrial companies shifted their primary activities towards finance and real estate (Kaika and Ruggiero, 2016). While manufacturing employment declined, the concomitant rise in employment in the service sector has been characterised by insecure and low-waged contracts (Gallino, 2009). Up to the beginning of the global financial crisis (GFC), precarization and impoverishment were balanced by rising house prices. However, the combination of the GFC and the austerity policies adopted caused a severe deterioration of material conditions for the most vulnerable (Di Feliciantonio, 2016a; 2017b). The GFC also caused a collapse in construction levels, house prices, and levels of market activity, while growing indebtedness levels have led to an increase of foreclosures and evictions (Bazzoli, 2018; Di Feliciantonio, 2017b). In Rome, approved evictions were less than 6000 in the years preceding the crisis, increasing to 8729 in 2009 (Di Feliciantonio, 2017b: 714). While evictions increased, public intervention to relieve the housing crisis has remained inadequate, only 750 new social housing units were built in the period 2008-2013, while 30,000 households were eligible in the official lists. The case of Rome reflects a national trend. According to Eurostat data, the social protection benefits for "housing and social exclusion" in Italy corresponded to just $0.1 \%$ of the GDP in 2009. Despite the ongoing housing crisis and the decrease of real estate values, vacancy rates in the Italian capital have 
not decreased, with more than 41,000 residential buildings ( $10.5 \%$ of the total stock) vacant in the overall province of Rome and around 60,000 housing units estimated to be unsold (Di Feliciantonio, 2017b; 2017c). Constrained by austerity, the response of official institutions has been to reaffirm neoliberal policies. The market approach to housing remains dominant, with homeownership favoured and investment in social housing marginal (Di Feliciantonio and Aalbers, 2018).

In Ireland, the so-called Celtic Tiger era (1993-2007) saw a dramatic transformation of the economy. While the first phase of expansion was based on export-led growth through foreign direct investment, by 2002 a debt-fuelled property bubble had taken over as the main economic driver. Between 1991 and 2006, 762,541 housing units were built nationally, while house prices rose by $429 \%$ in Dublin and $382 \%$ in the country as a whole (Kitchin et al, 2012). In tandem, the state shifted housing policy away from the direct provision of social housing, instead tying it to the private sector delivery of homes through new planning measures and a policy of housing social housing tenants in the private rental sector through the payment of a state-subsidy to landlords (Byrne and Norris, 2017). As noted by Waldron and Redmond, (2014: 151), the impact of these shifts was that "mortgaged households increased by 18 per cent between 2002 and 2006 from 484774 to 569 966... [while between] 1999 and 2009, Ireland's ratio of residential mortgage debt to GDP increased from 29 to 92 per cent, whereas per capita mortgage debt increased from $€ 7,000$ to approximately €33,000". From 2007 onwards, Ireland's economic boom collapsed, resulting in a dramatic and severe housing and financial crisis and recession. House prices fell by $57.4 \%$ in Dublin and $48.7 \%$ in the rest of the country. Unemployment soared from a low of $4 \%$ in 2004 to a peak of more than $15 \%$ by 2011 (Kitchin et al, 2012). In late 2010, the Fianna Fáil government agreed to an €85 billion IMF-EU-ECB bailout programme, and successive governments responded with a series of harsh austerity budgets in the ensuing years.

The impact of the crisis on housing has been severe. One of the most visible outcomes was a landscape of unfinished and vacant residential and commercial developments, most prominently so-called 'ghost estates'. The 2011 census reported that 230,086 units nationally were vacant (excluding holiday homes) out of a total housing stock of $1,994,845$ (CSO, 2012). This was combined with growing levels of mortgage arrears, which peaked in Q3 of 2013 at $12.9 \%$ of all principal residence mortgages $(99,189)$ in arrears of over 90 days 
(Central Bank, 2017). In contrast to Italy, Ireland has had relatively low levels of evictions from mortgaged principal dwelling homes: 5,568 repossessions in the period 2012-2016, although, repossessions did show an increase in 2016 (Hearne et al, 2018). However, the government response to the crisis in terms of measures to save financial institutions (i.e. the creation of the 'bad bank' the National Asset Management Agency, NAMA, see Byrne 2016), to privilege the continued valorisation of property and homeownership, and the implementation of austerity (Mercille and Murphy, 2015) has spread housing insecurity to a wider section of the population. From 2008 to 2013, exchequer capital funding for new social housing was cut by $90 \%$, resulting in an almost complete cessation. In the private rental sector, rents have increased at a rate of $13.5 \%$ on an annual basis nationally, and rents in Dublin have risen by $15 \%$ per year (a 65\% increase from their lowest point in 2010) (Daft, 2016). Consequently, homelessness has increased dramatically as a result of evictions from the private rental sector, and family homelessness emerged as a major issue from 2014 onwards. In Dublin, the epicentre of this new crisis, 5,480 adults accessed homeless accommodation in 2015 , increasing to 6,314 for 2016 . The number of homeless families has likewise grown from 598 in March 2016 to 1,296 (with 2,916 children) in November 2018².

As such, like Italy, in Ireland the institutional response to the crisis has continued to reify the approach to homeownership and the furthering of neoliberal policies. While evictions from mortgaged homes were not initially as severe, the wider response to the crisis has intensified housing insecurity. The violence of the crisis has been slower to reveal itself in Ireland. This has also influenced activist responses, which have necessarily intervened in the homelessness emergency rather than building more expansive forms of "commoning" . In both of these countries, then, the issue of property has become intensely politicised through the concomitant visibility of large-scale vacancy (viewed as an outcome of the property-driven crisis) and the burgeoning precarity with regard to accessing secure housing. Within this context, we can see the tension between the deepening neoliberal hegemony of the police order and the opening of the political through property as a site of struggle.

\footnotetext{
${ }^{3}$ Compiled from Dublin Regional Homeless Executive data (various dates). See http://www.homelessdublin.ie/homeless-statistics
} 


\section{The return of the political: contentious property initiatives in Rome and Dublin}

A series of very different squatting initiatives emerged across Italy after 2010. Operating broadly under the banner of the "urban commons", such initiatives brought together new mottos, practices, and strategies (Di Feliciantonio, 2017b; 2017c; Giubilaro, 2018). Rome was at the forefront of this political process. Abandoned theatres and cinemas were occupied by groups of precarious cultural workers who organized to claim the 'right to culture' (Di Feliciantonio, 2016a). The case of Teatro Valle, one of the most ancient theatres in the historical city centre, was emblematic. In June 2011, a group of cultural workers (actors, technicians, etc) began an occupation of the theatre, which had been shut down due to funding cuts. The aim was to make the effects of austerity politics visible. While the initial aim was to retain the occupation for a period of days, the extraordinary support the group received convinced them to extend their project. This stimulated a new wave of occupations across Italy that claimed cultural facilities and urban space as commons. As argued by one interviewee:

"the occupiers of Teatro Valle embody urban precarity, living in a city where housing is unaffordable, (...), they decide to experiment with occupation and selfmanagement, their struggle becomes soon a national symbol of what politics can be. (...) They have shown that all our struggles are connected and working together can produce a change" (Housing activist QF1, personal interview, June 2013).

Beyond cultural spaces, the new squatting wave also focused on housing. Growing poverty and housing insecurity following the crisis was worsened by the lack of municipal intervention in housing due to austerity The response of the main squatting networks of the city (ACTION- Diritti in Movimento, Blocchi Precari Metropolitani and Coordinamento di Lotta per la Casa) was concerted, as demonstrated by the launch of the 'Tsunami Tour' between 2012 and 2014, which simultaneously occupied several buildings across the city in order to provide shelter for thousands of people. While a full analysis of these projects goes beyond the scope of the paper, their political dimension is revealed by considering the people and the practices involved.

Those involved in these initiatives were mainly young indebted people who experienced precarization most intensely, migrants "expelled" from the welfare system (Di Feliciantonio, 2017b), and students who experience reduced levels of services and support (Di 
Feliciantonio, 2016b). Following a Rancierian perspective, these subjects are the "part of no part" in the double sense that they were unaccounted for within the official political system while being impacted significantly by decisions taken in response to the crisis, and that hitherto there had been no discourse to recognise them as political subjects. The occupation of spaces (both for housing and cultural/work) represents their claims for equality in a system that does not offer them power. Moreover, the gesture of occupation itself represents the first step of the process of subjectification. However, in line with our reading of Rancière, the occupation is only a part of a series of practices of mutual aid, learning and support. In a similar manner to the PAH in Spain (Garcia-Lamarca, 2017a; 2017b), squatting initiatives in Rome enabled those involved to pursue objectives that went beyond sectorial claims (like housing or funding for cultural activities). Such practices were much less politically visible than the gesture of occupation and include, among others, creating selfmanaged language schools for migrants, autonomous services for women who experienced domestic violence, fundraising activities (dinners, parties) for specific issues and working spaces for migrants who do not have resources to rent a venue. The reclamation of property through occupation, therefore, represents a political act that challenges the police order (characterised by the defence of neoliberal rationality) while also opening up a space for political subjectification to occur through the praxis of everyday commoning.

The role of (vacant) property as a site of political antagonism was even more explicit in the Irish context. Large scale vacancy and unfinished developments was one of the most visible manifestations of Ireland's crisis. O'Callaghan et al (2014) show how vacancy, in particular 'ghost estates', became one of the main arenas of discursive struggle around which the post-political consensus was challenged, but ultimately reaffirmed through a narrative that viewed the crisis as the outcome of an "era of excess" (Ibid: 131). However, other more politicised readings were not completely erased; rather they were channelled into a variety of social movements and cultural experiments (O'Callaghan, 2017).

The severity of the housing crisis in Ireland has been slower to reveal itself given the comparative lack of evictions from mortgage homes. However, a new housing and homelessness crisis that has emerged since 2013 has reignited the issue and given rise to a wave of housing activism. Explicitly emerging in response to crises in the private rental sector and, in particular, the burgeoning homelessness emergency, the character of groups 
is diverse, including policy lobby groups, tenants unions, and neighbourhood-based grassroots groups focused on providing support for those facing eviction and living in emergency homeless accommodation (Hearne et al, 2018). Formed in 2015, the Irish Housing Network (IHN) has been a key umbrella organisation drawing together other groups ${ }^{4}$. Individual groups often operate on a neighbourhood basis to carry out support work and increasingly to block evictions, while larger direct actions and campaigns are carried out under the IHN banner and involve activists aligned with different groups. Significantly in terms of our argument in this paper, the IHN has been centrally involved the occupation of vacant properties, including two cases where they established functioning homeless shelters. As such, in Dublin occupations have focused on the political antagonism of homelessness rather than, comparatively, longer-term strategies to normalise squatting for housing need.

The first, the Bolt Hostel (July 2015) was in a building formerly owned by Dublin City Council (DCC), which had previously been used for emergency accommodation but had been vacant for a number of years at the time of the occupation. The activists publicly announced the occupation at the conclusion of a protest march through a banner drop. Cleaning the property and renaming it the Bolt Hostel, the activists opened the building to house homeless families and rough sleepers. The second, Apollo House (December 2016 to January 2017) was a much larger action involving a coalition of housing activists, trade unions and artists. Garnering substantial media attention and public support, the occupation staged a political intervention in a building under the control of the state's 'bad bank' NAMA. In both these cases, the actions offer an example of insurgent moments that stage the political. Firstly, the occupations created a space in which the homeless and housing insecure appear as political subjects; their presence in urban space disrupts both established understandings of 'the homeless' and the neoliberal norms that have driven the narrative of recovery. As such, the actions create "discourse" where there was only "noise". Secondly, this staging of a "wrong" is relationally constructed through the resurrection of politicised readings of the crisis narrative. The occupations draw attention to the unresolved nature of vacancy following the crisis to once again disrupt the narrative of a 'specific'

\footnotetext{
${ }^{4}$ It should be noted here that the scale of Irish housing activism remains relatively small despite the significant growth in recent years. While the umbrella structure allowed for the formation of local groups, there is a clear disparity in size and levels of activity of different groups associated with the IHN.
} 
problem and show how vacancy is a systemic expression of inequalities that expose society's inherently undemocratic character. As one of the activists involved in the Bolt Hostel put it:

"...part of [the action] was to show that these buildings were in good condition and could feasibly be restored and also just the silliness of having a formally homeless hostel closed during a period where rough sleeping was increasing enormously and homeless families were increasing enormously... it was just a waste... It forced [Dublin City Council] to answer for what was happening and I think it got a huge amount of media attention around the issue of vacancy" (Housing activist 1 Dublin, personal interview, May 2016).

Taken together, the cases of Rome and Dublin reveal how the insurgent moment of occupation that stages the political is enabled by and contingent upon the particular properties of the police order as it attempts to "account" for the crisis. What we mean by this is that the crisis is, in and of itself, a period of disruption whereby the dominant models of development and narratives of progress are thrown into disarray. Property as a set of normative social relations (Blomley, 2016) was indeed destabilised. The "wrong" exposed by the subjects involved in occupations hinged upon wider cracks in the post-political consensus produced by the crisis, which found expression in property as a material symbol of the inequality engendered by the austerity response. Thus, to draw conceptual comparisons to Nancy (2007), the way in which the police order brings society into view as it adapts to the crisis also enables alternative "world forming" to appear in response and in opposition to it. The pivot of the crisis is significant in terms of opening up space to "expose a wrong", but this "wrong" is both relational to the dominant model of society and enacted in contextual ways through particular spaces. Similarly, as we highlight in relation to less visible commoning activities in Rome (but which could also be applied to Dublin, see O'Callaghan, 2017), the processes of subjectification extends well beyond the period of insurrection. While the gesture of squatting is characteristic of disruptive politics, the series of practices enabled by, and extending from, the occupations are indicative of Nancy's (1997: 90) conceptualisation of political community as the "form of being-toward in beingtogether". 


\section{The limits of the political and the reaffirmation of the police order}

The limited violence of the crisis

In Ireland, the impact of the crisis has been limited in terms of home repossessions, with just over 7,000 civil bills for repossession lodged at the beginning of 2015 (Waldron, 2016: 65), although this rate is expected to increase because of new bankruptcy norms. We can contrast this with Spain, where an estimated 250,000 households were evicted between 2008 and 2014 (Garcia-Lamarca and Kaika, 2016: 322), a contributing factor to the widespread politicisation of housing. Nevertheless, mortgage arrears increased dramatically following Ireland's crisis: "as of June 2014, 126,000 primary residential mortgages (16.5\% of total mortgages) were in arrears and of these, almost half $(61,000)$ have been in arrears for more than one year and risk losing the home" (Waldron and Redmond, 2016: 485). Consequently, while Ireland has avoided the seismic housing readjustment created by widespread evictions, the situation has nevertheless created what Downey (2014: 134) calls an "omni-crisis" in housing insecurity for a growing section of the population. Within this context, activists have attempted to highlight the interconnected nature of the housing crisis, but acknowledge that the uneven ways it impacts populations make it difficult to create popular support for systemic change.

"[The crisis affects] families and people who are homeless and migrants and unemployed people, all the groups that are so discriminated against on the fringe of society. But housing affects so much more than them, they are just the ones who are most intensely pushed. (...) [The crisis] has bought sympathy that housing isn't working, but the group that are fighting are at the bottom (...) And it's one of the deepest crisis in Irish society (...) housing will just continue to get worse" (Housing activist 2, personal interview, June 2016).

Government policy(ing) has exploited this by emphasising homelessness as a 'specific' issue that can be addressed through a range of technocratic solutions. We can see these technocratic discourses at work in the government's main strategy on housing, Rebuilding Ireland (Department of Housing, 2016). Then Minister for Housing Simon Coveney outlined the aim of the strategy to provide "more homes at an affordable price, in places where they are needed, and a reduction in the numbers of homeless people in hotels and emergency accommodation" (Ibid: 7). While touted as an ambitious government intervention in the 
crisis, an analysis reveals the continuation of the same set of neoliberal policies. For instance, despite evidence of mounting evictions of tenants on the Housing Assistance Payment (HAP) scheme due to rent increases (Hearne and Murphy, 2018), the projections in Rebuilding Ireland (p. 46) envision that by 2021 half of all social housing will be provided through HAP, thus failing to acknowledge fundamental problems with this model. Other measures to address homelessness included the erection of rapidly built modular housing units, on a temporary basis, on state-owned land, and the widespread adoption of homeless "family hubs" that provide specific emergency accommodation for homeless families (Hearne and Murphy, 2018). Although these measures have a short-term remedial effect, and may improve the lives of homeless families (Nowiki et al, 2018), they do not address the underlying causal factors of the crisis. In place of systemic policy change, the discursive tactic has instead been to reduce the housing crisis to a fundamental problem of supply. The key policy objective, therefore, is to increase supply through removing barriers to development (including the introduction of "fast-track" planning), incentivizing the construction and investment sector through a mixture of specific incentive schemes (targeting areas like vacant housing) and a reduction of development obligations, as well as the introduction of a tax rebate for first-time buyers (Help to Buy Scheme) and a Government backed mortgage (Rebuilding Ireland Home Loan). Thus, the police response has been a combination of short-term "emergency" interventions in homelessness and technocratic solutions to market failure designed to re-incentivise supply.

In Italy, evictions formed a major political antagonism. Evictions approved by the courts were 33,768 in 2005 , increasing to 56,269 in 2010 and getting to 69,250 in $2014^{5}$. As noted above, data concerning the province of Rome followed a similar increase. This (more) limited impact of the housing crisis seems to have somehow lowered the potential for a large social movement to spread, a point shared by activists. For instance, OYG, housing activist, argues:

"the fact that the crisis has concerned a limited amount of people, and maybe specific groups like young households, migrants or maybe retired old people makes people believe this is not going to happen to them, maybe they have a family house

\footnotetext{
${ }^{5}$ Italian Ministry of Internal Affairs Data available online: http://ucs.interno.gov.it/FILES/allegatinews/1263/Pubblicazione_sfratti_2016.pdf [last visit: 28 December 2017]
} 
to use as asset or they simple have family support, (...) this is always the same issue in this country, if you don't have a family supporting you, you are fucked" (personal interview, July 2016).

This quote expresses the difficulties of creating participation and consensus around the housing crisis in a context where evictions have increased but do not represent a mass phenomenon, and where the dynamics of the welfare system make young people rely on, often precarious, family support (Di Feliciantonio, 2017c). In Italy the housing crisis has been represented by the police order as a momentary, technical issue that can be addressed through neoliberal reforms. For example, the 'Lupi Bill', approved by the Renzi Government in 2014 to solve the housing crisis, on one hand introduced temporary financial aid for 'non guilty' (incolpevoli) defaulting tenants and those in private rental, while on the other introduced a more advantageous tax regime for landlords in all the large cities and main provincial towns, i.e. the so called cedolare secca (lowered to 10\%). Moreover, the plan favoured the dismissal of social housing (art.3) through the institution of a sort of 'right to buy' scheme for social housing tenants. Under the new law, new social housing tenants are allowed to buy their unit after seven years. The Bill, thus, discursively 'accounts' for a crisis in housing affordability while accelerating privatisation.

'Legality' and (market) 'rules' to disavow alternative practices

To respond to the projects contesting private property, mainly squatted spaces, both the national government and the local government in Rome have approved new measures aimed at punishing squatters in the name of 'legality'. Art. 5 of the abovementioned Piano Casa states that electricity and water facilities cannot be installed anymore without providing a legal entitlement to the property. The same article excludes squatters from the right to apply for social housing for five years. In a context where squatting has a longstanding tradition, these articles highlight the will of the police order to punish squatters through recourse to technocratic logic of 'rules'. In Rome, such a logic has been deepened by Deliberation 140 approved by the city government in 2015, aimed at re-establishing the control over the properties of the city council in order to guarantee their profitability and avoid 'public money waste'. Any group or association renting a property owned by the city council whose lease was about to expire was notified an eviction order. Those refusing to 
leave the property were asked to pay rents calculated at (private) market rates, rather than the subsidized ones usually granted to NGOs or non-profit organizations.

The same logic has been applied to squatters of buildings owned by the city council, who have been asked to pay an occupation allowance for the entire period of the occupation calculated at market prices. Therefore, some squatted spaces have received payment requests for hundreds of thousands of Euros, leading in some case to their eviction. This highlights the market logic behind the overall institutional response, which emphasises the economic over the social value of public property.

Beyond these new legal measures, different kinds of 'rules' have been instrumentally used by institutions in order to evict squatted spaces. For example, concerns about the 'safety' of occupied buildings and spaces were used by institutions to forward a discourse that initiatives need to be evicted because people living there are at risk of fires, gas explosions and similar kinds of incidents. This response has been adopted, for example, in the case of an occupation - mostly housing African refugees since 2013 - in the central Piazza Indipendenza evicted in the summer of 2017. In such cases, people have been violently evicted without being provided alternative accommodation. In the Piazza Indipendenza example, after days of demonstrations and intense political debate a partial solution was only identified for around 110 people (who were transferred to the provincial town of Rieti). This example reveals how 'safety' embodies a managerial instrumental rule used to avoid any serious political debate around the lack of appropriate housing and migration policies. However, it also shows how the managerialism of the police order is supported by violence.

While not deployed as pervasively, we can nevertheless see the use of legal instruments and discourses to disperse occupations in the Irish context. For example, for activists involved in the Bolt Hostel, the initial aim of the project had been to negotiate with DCC to keep the hostel open. However, DCC instead used trespass law to initiate legal proceedings against two of the activists involved. The basis of the legal argument put forward was that the building was structurally unsound, and posed a health and safety hazard to the occupiers. Such managerial approaches to 'safety' were also evident in the example of Apollo. The property owners applied for a court injunction against the occupiers, which was granted, but with a stay of execution for a period of approximately three weeks. During this interim, the activists navigated the potential safety concerns by allowing an established 
homelessness charity access to the building to assist in the delivery of the 'service'. Nevertheless, activists and volunteers were critiqued on the basis that they lacked the 'professional' qualifications to provide homeless services. For example, mainstream media significantly amplified the views of Independent Councillor Mannix Flynn who accused the activists of "exploiting" homeless people for political aims (Holland, 2017). Indeed, following the end of the occupation Flynn was invited onto Ireland's premier chat show, The Late Show, where he reiterated his claims that Apollo House had "completely failed", was "deeply exploitative", and "an illegal occupation" (Ní Aodha, 2017). This example shows the difficulties involved in creating a sustained break with the police order. The insurgent moment of occupation sought to stage the homeless and housing insecure as political subjects in order to shatter the existing system of housing. In practical terms, however, the occupation involved vulnerable actors. Thus, the police order was able to deploy a discourse of 'safety' to set up a dichotomy between the 'professional' care delivered by established service providers and the interventions of 'amateurs', which was constructed as potentially dangerous. This allowed for the insurgent action to be partially re-captured by the technocratic logics of the police order, thus limiting its radical and transformative impacts.

\section{Coda: Take Back the (Feminist) City}

Throughout August and September 2018 housing activists undertook a wave or rolling occupations of vacant properties in Dublin's inner city. Organised under the banner of "Take Back the City", the actions were coordinated by a coalition of housing action and migrants' rights groups, most of which had aligned themselves with the IHN since its relaunch in June of that year. Following a fallow period after the fragmentation of groups involved in Apollo House, "Take Back the City" sought to stage a "festival of direct action" that positioned the housing crisis at the central political issue in the city. Starting with the occupation of a set of properties on Summerhill Parade - previously rented to mainly Brazilian migrants who were living up to twenty per unit in cramped conditions - the groups subsequently occupied two other properties and organised a spate of associated rallies, talks, marches and actions. Using the occupied properties as nodes, the activists extended the tactics of occupation to "pop-up" and disrupt the wider city through actions involving performative and subversive spectacle. The set of actions, strategies and tactics involved in "Take Back the City" clearly 
drew on the experiments of The Bolt Hostel and Apollo House: the targeting of particular vacant properties to exemplify housing inequality, the mobilisation of actions and protests surrounding the occupations to promote the group's demands and generate wider public support, the use of social media to amplify the actions and shape a narrative about the housing crisis, and the strategic use of legal injunctions to force property-owners to identify themselves, and indeed, in the case of the occupation of a property on Frederick Street, to mobilise private security abetted by the police force to violently evict the protesters. All of these tactics had antecedents in the previous occupations. But "Take Back the City" also unfurled in significantly different ways. The narrative framing was shifted from homelessness to wider housing insecurity, particularly focused on rental housing and exploitative "slum landlords"6, while also extending to include migrants' rights as a central concern.

During 2018, several demonstrations were organized in Rome by feminist groups protesting the eviction order served on two main feminist spaces of the city: the International Women's Home (running since the 1980s and fully legalized since 2001) and Lucha Y Siesta (squatted since 2007, providing a shelter for women who survived domestic abuse). The eviction order for the former came from the abovementioned Deliberation 140, while the latter resulted from a decision to sell the real estate of the city public transport company. These demonstrations intersected with the massive national mobilization of Non una di meno, emerged in Italy in 2016 as a response to increasing feminicide. Those involved in demonstrations rejected the economic value of public properties as promoted by the city council, instead re-affirming the importance of use value for those who do not find adequate support from formal institutions (e.g. women who survived domestic abuse) as well as privileging the autonomy of the feminist movement. To the city council's argument about the need to maximize economic value on its properties, both the groups have published documents and data revealing the economic value of the activities they produce for free. For instance, in the case of Lucha Y Siesta, this value is estimated at $€ 4 \mathrm{~m}^{7}$. Thus, the long-standing practice of squatting comes to coexist with the language of 'economic value', while also addressing several other political issues (domestic abuse, shortages of social

\footnotetext{
${ }^{6}$ See for instance the Slumleaks blog which was used to publish details on the owners of the properties under occupation.

${ }^{7}$ Source: https://luchaysiesta.files.wordpress.com/2019/02/lucha-y-siesta-dossier.pdf [retrieved 27/03/2019]
} 
housing and services, abandoned buildings). The main outcome of these mobilizations, thus far, has been the absence of eviction and the opening of special commissions to guarantee the continuation of the projects.

To conclude this paper we want to reflect back on our conceptual arguments regarding the need to shift our understanding of Rancierian politics. The examples of "Take Back the City" in Dublin and feminist movements in Rome can be understood as "interrupting" the forms of political community advanced through previous occupations - at once picking up the process political subjectification they enacted while simultaneously "unworking" their claims to inclusivity in order to frame new forms of "being-in-common". Seeking to move beyond those analyses framing the political and the moment of rupture as 'all or nothing', we have tried to emphasize how disruption is relationally connected to the police order, i.e. political gestures are always local and situated, they do not emerge from a hypothetical 'outside'. Because of this local character of the political gesture, it tends to remain limited, the police order working to cover its disruption. However, this process is always partial, and therefore potentially transformative, in at least two respects. Firstly, the police order needs to accommodate some of the interests brought by the new political subjectivities produced through the political moment, thus being transforming itself. Secondly, even if the democratic moment represented by political subjectification cannot produce a radical break with the police order, this does not imply that forms of community inscribed through these processes are simply erased. Reading political subjectification through the lens of Nancy's concepts of "interruption" (1991) and the "tying and untying" of community can frame postcrisis urban politics in ways that help move beyond, firstly, the designation of the contemporary era as post-political and, secondly, the circular debates on the nature and destiny of the "properly political" act.

In our analysis we have shown how the police order has made use of 'rules' to foreclose emerging political initiatives, while acknowledging the role of structural elements of 'excess', such as a more limited number of evictions, in determining the possibilities for the political gesture to proliferate. But even if eventually quelled, these moments - and indeed longer term processes - of political subjectification ultimately, inevitably, transform the police order. These processes are indicative of the ways in which one wave of political action enables the conditions under which subsequent waves of action can come into being while, 
hopefully, not constricting the set of proliferating relations it may produce. Already various scholars (Garcia-Lamarca, 2017a, 2017b; Temenos, 2017) are seeking ways to conceptually and empirically move beyond the theoretical deadlock of the "post-political" in order to investigate the emergent, ambivalent, urban and political landscapes of the post-crisis period. Ours is a gesture and critical intervention into this political unknown: "for everything remains to be invented" (Nancy, 2016: 121).

\section{References}

Bazzoli N (2018) Lottare Per La Casa Nel Quartiere Che Cambia Volto. II Potenziale Politico dei Commons Urbani. ACME 17(2): 269-291.

Beveridge R and Koch P (2017) The post-political trap? Reflections on politics, agency and the city. Urban Studies 54(1): 31-43.

Blomley N (2016) The territory of property. Progress in Human Geography 40(5): 593-609.

Brenner N, Peck J and Theodore N (2010) Variegated neoliberalization: geographies, pathways. Global Networks 10(2): 182-222.

Bresnihan P and Byrne M (2015) Escape into the city: Everyday practices of commoning and the production of urban space in Dublin. Antipode 47(1): 36-54.

Byrne M (2016) 'Asset Price Urbanism' and Financialization after the Crisis: Ireland's National Asset management agency. International Journal of Urban and Regional Research 40(1): 31-45.

Central Bank (2017) Residential mortgage arrears and repossessions statistics. Available at: https://www.centralbank.ie/statistics/data-and-analysis/credit-and-bankingstatistics/mortgage-arrears

CSO (Central Statistics Office) (2012) Profile 4: A roof over our heads. Available at: http://www.cso.ie/en/media/csoie/census/documents/census2011profile4/Profile 4 The Roof over our Heads Full doc sig amended.pdf

Crouch C (2004) Post-Democracy. Cambridge: Polity.

Daft (2016) The Daft.ie rental price report 2016. Available at: http://www.daft.ie/report/2016-q4-rental-daft-report.pdf 
Dean J (2009). Democracy and other neoliberal fantasies: Communicative capitalism and left politics. Durham: Duke University Press.

Department of Housing (2016) Rebuilding Ireland. Government of Ireland.

Derickson KD (2017) Taking account of the 'part of those that have no part'. Urban Studies 54(1): 44-48.

Di Feliciantonio C (2016a) Subjectification in times of indebtedness and neoliberal/austerity urbanism. Antipode 48(5): 1206-1227.

Di Feliciantonio C (2016b) Student migrants and squatting in Rome in times of austerity and material constraints. In: Mudu P and Chattopadhyay S (eds) Migrations, Squatting and Radical Autonomy. London: Routledge, pp. 93-98.

Di Feliciantonio C (2017a) Social movements and alternative housing models. Practicing the "politics of possibilities" in Spain. Housing, Theory \& Society 34(1): 38-56.

Di Feliciantonio C (2017b) Spaces of the Expelled as Spaces of the Urban Commons? Analysing the Re-emergence of Squatting Initiatives in Rome. International Journal of Urban and Regional Research 41(5): 708-725.

Di Feliciantonio C (2017c) The reactions of neighbourhoods to the eviction of squatters in Rome: An account of the making of precarious investor subjects. European Urban and Regional Studies 24(4): 352-367.

Di Feliciantonio C and Aalbers MB (2018) The Prehistories of Neoliberal Housing Policies in Italy and Spain and Their Reification in Times of Crisis. Housing Policy Debate 28(1): $135-151$.

Dikeç M (2005) Space, politics and the political. Environment and Planning D 23(2): 171-188.

Dikeç M and Swyngedouw E (2017) Theorizing the politicizing city. International Journal of Urban and Regional Research 41(1): 1-18.

Downey D (2014) The Financialisation of Irish Homeownership and the Impact of the Global Financial Crisis. In: MacLaran A and Kelly S (eds) Neoliberal Urban Policy and the Transformation of the City. Berlin: Springer, pp. 120-138.

Gallino L (2009) L'impresa irresponsabile. Turin: Einaudi. 
Garcia-Lamarca M (2017a) From Occupying Plazas to Recuperating Housing: Insurgent Practices in Spain. International Journal of Urban and Regional Research 41(1): 3753.

Garcia-Lamarca M (2017b) Creating political subjects: collective knowledge and action to enact housing rights in Spain. Community Development Journal 52(3): 421-435.

Garcia-Lamarca M and Kaika M (2016) 'Mortgaged lives': the biopolitics of debt and housing financialisation. Transactions of the Institute of British Geographers 41(3): 313-327.

Giubilaro C (2018) Undoing Commons: Diritto alla Città, Attivismo Culturale e Pratiche di Uncommoning nel Sud d'Italia. ACME 17(2): 325-47.

Haughton G, Allmendinger P and Oosterlynck S (2013) Spaces of neoliberal experimentation: soft spaces, postpolitics, and neoliberal governmentality. Environment and Planning A 45(2): 217-234.

Hearne R, O'Callaghan C, Di Feliciantonio C and Kitchin R (2018) The relational articulation of housing crisis and activism in post-crash Dublin, Ireland. In Gray N (ed) A century of housing struggles: From the 1915 rent strikes to contemporary housing activisms. Bolder: Rowman and Littlefield, pp. 153-168.

Hearne R and Murphy M (2018) An absence of rights: Homeless families and social housing marketization in Ireland. Administration 66(2): 9-31.

Holland K (2017) What exactly did the Apollo House occupation achieve? Irish Times, 13 January.

Kaika M and Karaliotas L (2016) The spatialization of democratic politics: Insights from Indignant Squares. European Urban and Regional Studies 23(4): 556-570.

Kaika M and Ruggiero L (2016) Land financialization as a "lived" process: The transformation of Milan's Bicocca by Pirelli. European Urban and Regional Studies 23(1): 3-22.

Karaliotas L (2017) Staging Equality in Greek Squares: Hybrid Spaces of Political Subjectification. International Journal of Urban and Regional Research 41(1): 54-69.

Kitchin R, O'Callaghan C, Boyle M, Gleeson J and Keaveney K (2012) Placing Neoliberalism: The Rise and Fall of Ireland's Celtic Tiger. Environment and Planning A 44(6): 13021326. 
Mercille J and Murphy E (2015) Deepening Neoliberalism, Austerity, and Crisis: Europe's Treasure Ireland. Basingstoke: Palgrave Macmillan.

Nancy J-L. (1991) The inoperative community. Minneapolis: University of Minnesota Press.

Nancy J-L. (1997) The Sense of the World. Minneapolis: University of Minnesota Press.

Nancy J-L. (2000) Being Singular Plural. Stanford: Stanford University Press.

Nancy J-L. (2007) The Creation of the World, or Globalization. New York: State University of New York Press.

Nancy, J-L. (2016) The Disavowed Community. Fordham University Press: New York.

Ní Aodha G (2017) Mannix Flynn: 'Apollo House completely failed'. The Journal, 25 February. https://www.thejournal.ie/mannix-flynn-late-late-show-3258478-Feb2017/

Nowiki M, Brickell K and Harris E (2018) Home at last: Life in Dublin's rapid build housing. Dublin: Dublin City Council.

O'Callaghan C (2018). Planetary urbanization in ruins: Provisional theory and Ireland's crisis. Environment and Planning D: Society and Space 36(3): 420-438.

O'Callaghan C, Boyle M and Kitchin R (2014) Post-politics, crisis, and Ireland's 'ghostestates'. Political Geography 42: 121-133.

O'Callaghan C, Di Feliciantonio C and Byrne M (2018) Governing urban vacancy in post-crash dublin: contested property and alternative social projects. Urban Geography 39(6): 868-891.

Rancière J (1995) Politics, identification, and subjectivization. In: Rajchman J (ed) The identity in question. New York: Routledge, pp. 63-70.

Rancière J (1999) Disagreement. Minneapolis: University of Minnesota Press.

Rancière J (2000) Le partage du sensible: Esthétique et politique. Paris: La Fabrique.

Rancière J (2012) Proletarian Nights: The workers dream in nineteenth-century France. London: Verso.

Robinson J (2011) Cities in a world of cities: the comparative gesture. International Journal of Urban and Regional Research 35(1): 1-23. 
Swyngedouw E (2009) The Antinomies of the Postpolitical City: In Search of a Democratic Politics of Environmental Production. International Journal of Urban and Regional Research 33(3): 601-620.

Swyngedouw E (2011) Interrogating post-democratization: Reclaiming egalitarian political spaces. Political Geography 30: 370-380.

Swyngedouw E (2014) Where is the political? Insurgent mobilisations and the incipient 'return of the political'. Space and Polity 18(2): 122-136.

Temenos C (2017) Everyday proper politics: rereading the post-political through mobilities of drug policy activism. Transactions of the Institute of British Geographers 42(4): 584-596.

Tocci W (2009) L'insostenibile ascesa della rendita urbana. Democrazia e Diritto 1/2009: 1759.

Waldron R (2016) The "unrevealed casualties" of the Irish mortgage crisis: Analysing the broader impacts of mortgage market financialization. Geoforum 69: 53-66.

Waldron R and Redmond D (2014) The Extent of the Mortgage Crisis in Ireland and Policy Responses. Housing Studies 29(1): 149-165.

Waldron R and Redmond D (2016) Stress in Suburbia: Counting the Costs of Ireland's Property Crash and Mortgage Arrears Crisis. Tijdschrift voor Economische en Sociale Geografie 107(4): 484-501.

Watkin, C. (2013) Thinking Equality Today: Badiou, Rancière, Nancy. French studies 67(4): 522-534.

Žižek S (1999) The Ticklish subject: The absent centre of political ontology. London: Verso. 